\title{
A Study on Economic Loss of Tobacco Users in Madurai East Block
}

\author{
P.Ramasamy \\ Former Asst. Professor \& Research Co-ordinator, Department of Social Work, \\ Madurai Institute of Social Sciences, \\ Madurai, India
}

\begin{abstract}
Tobacco use can worsen poverty among users and their families since tobacco users are at much higher risk of falling ill and dying prematurely of cancers, heart attacks, respiratory diseases or other tobacco-related diseases. This reduces family income and imposes additional costs for health care. The present study deals with the Economic loss of tobacco users in Madurai East Block. The study is a descriptive study which was conducted in 6 villages covering 841 tobacco users. The major findings indicate that about $74.1 \%$ were spending less than Rs.50 per day. There were negligible percentages of respondents in higher categories of expenses on the use of tobacco products. Three fourth of the respondents (74.4 $\%$ did not suffer economically due to use of tobacco, because the expenses were manageable and there was a balance between their income and expenses. A vast majority $(95.2 \%)$ of the respondents borrowed up to Rs. 2000 for treatment of tobacco related diseases. The debt of vast majority of the respondents was up to Rs.2000 as they underwent frequent treatment for minor health problems. Only $2.7 \%$ of the respondents had sold their ornaments.
\end{abstract}

Keywords: Economic loss, Tobacco use

Acknowledgement: This article is a part of the UGC sponsored major research project titled An Action research project towards creating a tobacco free zone.

\section{Introduction}

Tobacco consumption is the single most important avoidable factor in the growth of non communicable diseases in developing countries, particularly in India. Tremendous economic growth has spurred a visible rise in disposable incomes and in the affordability of tobacco products in the country. As international and domestic tobacco companies apply ever more effective tobacco marketing strategies in this large and rapidly developing economy, the risk of an increase in tobacco consumption remains significant.

Tobacco use causes economic loss to the individuals, Families and the nation at large. The World Health Organization (WHO 2013) estimates that, globally, smoking causes over US $\$ 500$ billion in economic damage each year.

In most countries, tobacco use tends to be higher among the poor. Poor families, spend a larger proportion of their income on tobacco. When money is spent on tobacco difficulties arise in spending on basic human needs such as food, shelter, education and health care. Tobacco can also worsen poverty among users and their families since tobacco users are at much higher risk of falling ill and dying prematurely of cancers, heart attacks, respiratory diseases or other tobaccorelated diseases. This will deprive income of the families and impose additional costs for health care. Although the tobacco industry provides jobs for thousands of people, the vast majority employed in the tobacco sector earn very little, while the big tobacco companies reap enormous profits. Globally, $84 \%$ of smokers live in developing and transitional economy countries.(WHO 2004).

\section{Review of Literature}

The nexus between tobacco consumption and poverty is well-documented; however, the tobacco control measures are uniformly applied, without due consideration for the high-risk target group. In India, nearly 300 million people live in extreme poverty ( UNDP 2017) About $28.6 \%$ of the population consume tobacco(GATS 2017). Nationally representative surveys and communitybased studies have shown that tobacco consumption among the poor has continued. The cyclical relationship between tobacco use among the poor and exacerbation of poverty due to 
tobacco-related diseases is also well-documented. Health care costs involve not only direct medical costs but also indirect morbidity and mortality costs (WHO 2014). India is a low- and middle-income country (LMIC). Government expenditure on health has continuously declined and public spending on health is $1.15 \%$ of gross domestic product (John 2005). Health expenditure is mostly out of pocket in India and it also consequently exacerbates the poverty rates due to high out-ofpocket expenditure for treatment of tobacco-related diseases. In India, socio-economic and health inequalities are rampant Tobacco-related diseases are a cause and consequence of poverty.(Subramanian 2008). It is not only merely a social and cultural problem but it is also multifaceted and encompasses biomedical, economic, and geopolitical (US NCI 2016). Tobacco use in India is projected to have devastating consequences.

Tobacco control policies have the opportunity to break this vicious cycle. Tobacco control should be a top priority not only merely as a health issue but also as a poverty reduction mechanism. Effective implementation of tobacco control policies provides an opportunity for India to fulfill its commitments to meet the goals - 2030 agenda of Sustainability Development Goal of poverty reduction and good health. Despite all the efforts, tobacco consumption is a major health issue globally, and in India, one-third of the population uses tobacco (IIPS 2010). And to provide targeted intervention, it is necessary to assess the tobacco epidemic and also evaluate the governing policies. The aim of this article is to synthesise the available scientific knowledge on tobacco use in India, with a view to assess the magnitude of the problem, reviewing the tobacco control legislation and its impact at the micro- and macro-level of tobacco control in India. The need for this comprehensive evaluation is to develop a better understanding of tobacco - consumption pattern, control policies, and the gaps that need to be addressed will serve as reference for developing pragmatic tobacco control approach.

Studies related to expense of individuals on tobacco use are sparse. But the total production of tobacco and expenses reveal the extent of use and expense in the society. India is the world's $2^{\text {nd }}$ largest producer of tobacco with an estimated annual production of around 800 million $\mathrm{kgs}$. Tobacco occupies a meager $0.24 \%$ of the country's total arable land area. It is grown largely in semiarid and rain-fed areas where the cultivation of alternative crops is economically unviable. The United States is the fourth largest tobaccoproducing country in the world, following China, India, and Brazil. Farms in the United States harvested more than 533 million pounds of tobacco in 2018. In 2018, two states-North Carolina and Kentucky-accounted for more than $70 \%$ of total tobacco cultivation.

\section{Methodology}

Descriptive research design has been adopted for this study. Out of 39 villages in Madurai East Block, 6 villages have been selected randomly using lottery method. The primary data were collected from the adolescents, middle age and old age people who were available between $9 \mathrm{am}$ and $6 \mathrm{pm}$ by using of interview schedule. Thus the study population comprised of 841 people (648 male and 193 female). Data were analyzed using frequency and percentage.

Table No: 1 Expenses of tobacco users for tobacco products per day

\begin{tabular}{|c|c|c|c|c|c|c|c|}
\hline \multirow{2}{*}{ S.No } & \multirow{2}{*}{$\begin{array}{c}\text { Expenditure on } \\
\text { tobacco products } \\
\text { per day }\end{array}$} & \multicolumn{4}{|c|}{ Sex } & \multirow{2}{*}{\multicolumn{2}{|c|}{ Total }} \\
\hline & & \multicolumn{2}{|c|}{ Male } & \multicolumn{2}{|c|}{ Female } & & \\
\hline \multirow[b]{2}{*}{1} & \multirow[b]{2}{*}{ Below Rs-50 } & $\mathbf{N}$ & $\%$ & $\mathbf{N}$ & $\%$ & $\mathbf{N}$ & $\%$ \\
\hline & & 450 & 53.5 & 173 & 20.6 & 623 & 74.1 \\
\hline 2 & Rs $51-100$ & 113 & 13.4 & 9 & 1.1 & 122 & 14.5 \\
\hline 3 & Rs $101-150$ & 21 & 2.5 & 4 & 0.5 & 25 & 3 \\
\hline 4 & Rs $151-200$ & 36 & 4.3 & 3 & 0.4 & 39 & 4.6 \\
\hline 5 & Rs $201-250$ & 4 & 0.5 & 1 & 0.1 & 5 & 0.6 \\
\hline 6 & Rs $251-300$ & 14 & 1.7 & 0 & 0 & 14 & 1.7 \\
\hline \multirow[t]{2}{*}{7} & Above - Rs 300 & 10 & 1.2 & 3 & 0.4 & 13 & 1.5 \\
\hline & Total & 648 & 77.1 & 193 & 22.9 & 841 & 100 \\
\hline
\end{tabular}


The above table reveals that 53.5 percent of male and 20.6 percent of female respondents were spending less than Rs.50 per day, while 13.4 percent of male and 1.1 percent of female respondents were spending Rs.51 to 100 for tobacco use per day. As least as 4.3 percent of male and 0.4 percent of female respondents were spending Rs.151 to 200 for tobacco use while 2.5 percent of male and 0.5 percent of female respondents were spending Rs.101 to 150 for tobacco use. There were negligible percentages of respondents in higher categories of expenses on the use of tobacco products.

Majority was spending up to Rs. 50 and some were spending Rs.51 - 100. Spending this much of amount is very heavy for those who are working for daily wages and those in low middle class. Majority of the respondents were manual workers and a considerable percentage of them were skilled laborers. Their earning was relatively less. So they did not go for high brand cigarettes and such other tobacco products. Others who spent more amounts of rupees were less in percentage.

Table No: 2 Extent of economic sufferings of tobacco users due to tobacco use

\begin{tabular}{|c|c|c|c|c|c|c|c|}
\hline \multirow{2}{*}{ S.No } & \multirow{2}{*}{$\begin{array}{c}\text { Extent of Economic } \\
\text { Sufferings due to } \\
\text { tobacco use }\end{array}$} & \multicolumn{2}{|c|}{ Sex } & \multicolumn{2}{c|}{} \\
\cline { 3 - 7 } & Very Much & $\mathbf{2}$ & $\mathbf{2}$ & $\mathbf{2}$ & \multicolumn{2}{c|}{ Total } \\
\hline 1 & & & & & & N & \\
\cline { 3 - 8 } & & 9 & 1.1 & 3 & 0.4 & 12 & 1.4 \\
\hline 2 & Much & 44 & 5.2 & 13 & 1.5 & 57 & 6.7 \\
\hline 3 & Moderate & 121 & 14.4 & 26 & 3.1 & 147 & 17.5 \\
\hline 4 & No & 474 & 56.4 & 151 & 18 & 625 & 74.4 \\
\hline & Total & 648 & 77.1 & 193 & 22.9 & 841 & 100 \\
\hline
\end{tabular}

From the above table it is observed that 14.4 percent of male and 3.1 percent of female respondents had moderate economic suffering while for 5.2 percent of males and 1.5 percent of females the economic sufferings was much. Only 1.1 percent of male and 0.4 percent of female respondents faced economic problems very much. But more than half of male (56.4 percent) and 18 percent of female respondents did not suffer economically due to use of tobacco.

Economic sufferings were not higher except among those who spent on treatment for health problems and de-addiction. Considerable percentages of respondents experienced much and moderate levels of suffering and very few suffered very much. Majority did not suffer economically because the expenses were manageable and there was a balance between their income and expenses. However

The amount spent is not going to improve their health or general life but it is going to deteriorate health and deprive them of basic needs. They have adjusted by reducing

their expenses in other aspects. Hence the sufferings are not explicitly known in many cases.

From the table 3 it is found that 73.8 percent of male and 21.4 percent of female respondents borrowed up to Rs. 2000 for treatment of tobacco related diseases while 1.3 percent of male and 0.4 percent of female respondents plunged into debt of above- Rs.10, 000. Percentage of respondents in other categories of expenses was less than one percent.

The debt of vast majority of the respondents was up to Rs.2000 as they underwent frequent treatment for minor health problems. This was because they could manage within their income and also majority of the labourers used to go to primary health centre and govt. hospitals. Further chief minister's health insurance scheme is utilized by the people in low income and hence they did not borrow much. 
Table No: 3 Amount of indebtedness due to treatment for tobacco related diseases

\begin{tabular}{|c|c|c|c|c|c|c|c|}
\hline \multirow[b]{2}{*}{ S.No } & \multirow{2}{*}{$\begin{array}{l}\text { Debt due to } \\
\text { treatment for } \\
\text { tobacco related } \\
\text { diseases }\end{array}$} & \multicolumn{4}{|c|}{ Sex } & & \\
\hline & & \multicolumn{2}{|c|}{ Male } & \multicolumn{2}{|c|}{ Female } & \multicolumn{2}{|c|}{ Total } \\
\hline & & $\mathbf{N}$ & $\%$ & $\mathbf{N}$ & $\%$ & $\mathbf{N}$ & $\%$ \\
\hline 1 & Below - Rs 2000 & 620 & 73.8 & 180 & 21.4 & 800 & 95.2 \\
\hline 2 & Rs $2001-3000$ & 5 & 0.6 & 2 & 0.2 & 7 & 0.8 \\
\hline 3 & Rs $3001-6000$ & 7 & 0.8 & 2 & 0.2 & 9 & 1.1 \\
\hline 4 & Rs $6001-10,000$ & 5 & 0.6 & 5 & 0.6 & 10 & 1.2 \\
\hline 5 & Above - Rs 10,000 & 11 & 1.3 & 3 & 0.4 & 14 & 1.7 \\
\hline & Total & 648 & 77.1 & 192 & 22.9 & 840 & 100 \\
\hline
\end{tabular}

Table No: 4 Sale of properties of the respondents for medical treatment

\begin{tabular}{|c|c|c|c|c|c|c|c|}
\hline \multirow[b]{3}{*}{ S.No } & \multirow{3}{*}{$\begin{array}{c}\text { Property sold For } \\
\text { Medical } \\
\text { Treatment }\end{array}$} & \multicolumn{6}{|c|}{ Sex } \\
\hline & & \multicolumn{2}{|c|}{ Male } & \multicolumn{2}{|c|}{ Female } & \multicolumn{2}{|c|}{ Total } \\
\hline & & $\mathbf{N}$ & $\%$ & $\mathbf{N}$ & $\%$ & $\mathbf{N}$ & $\%$ \\
\hline 1 & Land & 6 & 0.7 & 3 & 0.4 & 9 & 1.1 \\
\hline 2 & House & 2 & 0.2 & 0 & 0 & 2 & 0.2 \\
\hline 3 & Ornaments & 20 & 2.4 & 3 & 0.4 & 23 & 2.7 \\
\hline 4 & Goat & 12 & 1.4 & 5 & 0.6 & 17 & 2 \\
\hline 5 & Cow & 10 & 1.2 & 2 & 0.2 & 12 & 1.4 \\
\hline
\end{tabular}

From the above table it is found that 1.1 percent of the total respondents had sold their land, while 0.2 percent of male respondents sold their house for the expenses of medical treatment. 2.4 percent of male and 0.4 percent of female respondents had sold their ornaments. While 1.4 percent of male and 0.6 percent of female respondents sold their goats for medical treatment, 1.2 percent of male and 0.2 percent of female respondents sold their cows.

Few of the respondents met their expenses for medical treatment by selling their lands, house, ornaments, goat and cow. Lack of income or lack of savings usually results in sale of properties when treatment is necessary for major health problem. Hence some of the respondents sold some of the above said properties.

\section{Conclusion}

Tobacco users of this study generally were having poor economic status. Most of the respondents had the income of less than Rs 6000 per month. Hence the expenses on tobacco products definitely were the burden to them and the economic loss became heavy when they resorted to treatment for the illnesses caused by tobacco use. Hence the expenses due to tobacco use definitely results in greater economic loss and the solution depends on prevention of tobacco use.

\section{Bibliography}

[1] WHO | Tobacco increases the poverty of individuals and families https://www.who.int/tobacco/communic ations/events/wntd/2004/tobaccofacts_fa milies/en/

[2] Guindon GE and Boisclair D. Past, Current and Future Trends in Tobacco Use. HNP Discussion paper, Economics of Tobacco Control Paper No.6. February 2003

[3] World Health Organization's report on the global tobacco epidemic: enforcing bans on tobacco advertising, promotion and sponsorship. Geneva, Switzerland: 2013. [Accessed December 5, 2013]. 
[4] Availableat: http://apps.who.int/iris/bitstre am/10665/85380/1/9789241505871_eng.p df. [Google Scholar]

[5] John RM, Rao RK, Rao MG, Moore J, Deshpande RS, Sengupta J, Selvaraj S, Chaloupka FJ, Jha P. The Economics of Tobacco and Tobacco Taxation in India. Paris: International Union Against Tuberculosis and Lung Disease; 2010.

[6] Eriksen M, Mackay J, Schluger N, et al. The Tobacco Atlas external icon. Atlanta: American Cancer Society; New York: World Lung Foundation [accessed 2017 Nov 6].

[7] U.S. Department of Agriculture. Crop Production 2018 in 2015 Summary pdf icon[PDF-1.98 MB] external icon. Washington: U.S. Department of Agriculture, National Agricultural Statistics Service, 2019 [accessed 2019 Apr 9].

[8] UNDP . Poverty reduction and livelihoods promotion,

UNDP

in India. www.in.undp.org. Accessed July 17, 2017.

[9] GATS . Global Adult Tobacco Survey: fact sheet, India 2016-17; 2017. http://www.who.int/tobacco/surveill ance/survey/gats/GATS_India_201617 FactSheet.pdf
[10] MoHFW; WHO. Economic burden of tobacco related diseases in India: executive

summary; 2014. http://www.searo.who.int india/topics/tobacco/economic burden of tobacco_related diseases_in india exec utive_summary.pdf

[11] John, RM. Tobacco consumption patterns and its health implications in India. Health policy. 2005;71(2):213-222.

Google Scholar $\mid$ Crossref $\mid \underline{\text { ISI }}$

[12] Subramanian, SV, Ackerson, LK, Subramanyam, MA. Health inequalities in India: the axes of stratification. Brow J World Aff. 2008;14:127-138. Google Scholar

[13] US NCI and WHO. The economics of tobacco and tobacco control. National Cancer Institute (Tobacco Control Monograph 21, NIH Publication No.16CA-8029). Bethesda, MD; 2016. http://cancercontrol.cancer.gov /brp/tcrb/monographs/21/index.html. Google Scholar

[14] IIPS. Global Adult Tobacco Survey India, 2009-2010. New Delhi, India: Ministry of Health and Family Welfare, Government of India; 2010. Google Scholar 